\title{
Ethiopia is an Important Center of Crop Origin: A Proof from Archaeology and Anthropology
}

\author{
Alemayehu Kefalew ${ }^{1 *}$ and Sara Sintayehu ${ }^{2}$ \\ ${ }^{1}$ Department of Plant Biology and Biodiversity Management, Addis Ababa University, Ethiopia \\ ${ }^{2}$ Department of Natural Resource Management, Haramaya University, Ethiopia
}

*Corresponding author: A Kefalew, Researcher of Ethnobotany, Department of Plant Biology and Biodiversity Management, Addis Ababa University, Addis Ababa, Ethiopia

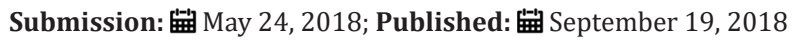

\section{Introduction}

From the perspectives of biodiversity and crop origin, is believed to be a land of topographic diversities [1] and home of multiple ethnic groups [2]. Moreover, it is known to be a land for the origin of both human kind and plants (Alemayehu
Kefalew and Sara Sintayehu, 2017). Globally Ethiopia is known to be part of biodiversity hotspot area. Below (Figure 1), the red marks, are Earth's biologically richest places with high number of species found nowhere else, and one of which is Ethiopia.

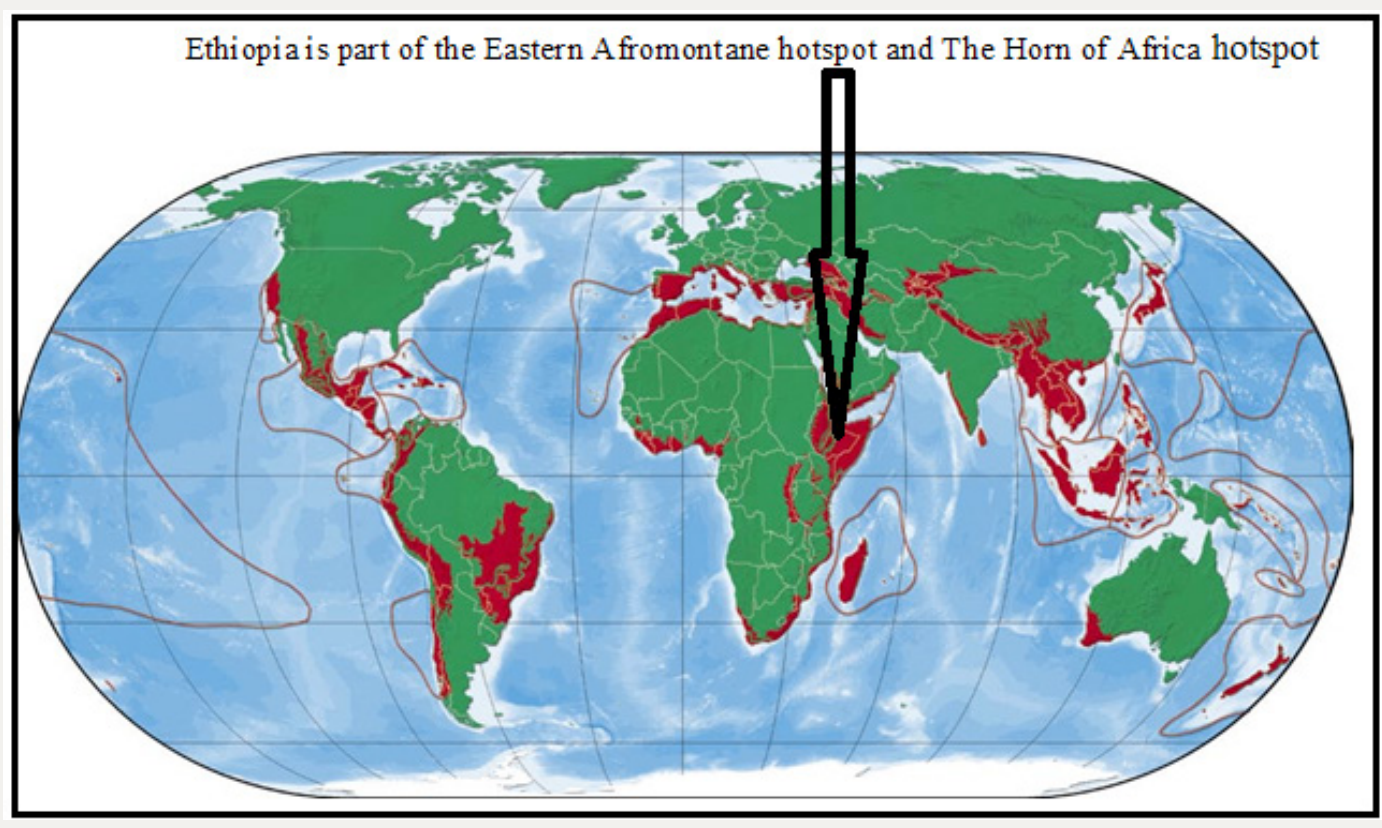

Figure 1: World map showing biologically richest places that encompass Ethiopia (indicated by red marks).

Archaelogical and Anthropological study showed that Ethiopia is also an important source of crop origin/diversity. In fact center of crop diversity and origin of agriculture were described first by Alphonse De Candolle [3] saw wild relatives of the major crops such as wheat, beans, rice. He proposed that the crops of the world originated in three centers.

1. Mesoamerica.

2. The Fertile crescent of the Middle East.
3. Southeast Asia. The criteria he used for recognizing centers of origin were:

a) Places where a plant grows spontaneously in the wild state.

b) Places where fragments of plants in old deposits and buildings (Archaeobotanical and Paleo botanical) are found.

c) Archives describing the adventures of travelers.

d) Philogical (naming) origin. 
The other notable scientist who made thorough investigation on crop origin was NI Vavilov [4]. He was a Russian germplasm collector and genetists. He studied the genetics, chromosome and anatomy of the germ plasm of crops he collected from five continents. Based on his studies he concluded that the most likely areas of origin were where the plant was cultivated and the wild ancestors grew [4]. Furthermore, according to Vavilov [5], the areas of Origin should be areas in which there was lots of variation. He was interested to see where can he find the wild ancestors of crops. Moreover, apart from his botanical explorations he also used evidences from archaeological excavations. In 1951 he published studies on the origin of cultivated plants which describes his theories on the origin of crops. Accordingly Ethiopia has been suggested to be the center of Crops such as Coffee (Coffea arabica), TEFF (Eragrostis tef), ENSET (Ensete ventricosum), NOUG (Guizotia abyssinica), ANCHOTE (Coccinia abyssinica), etc as they were/ are found in nature on the land of Ethiopia. The following map illustrates areas of crop origin according to Vavilov [6], (Figure 2).

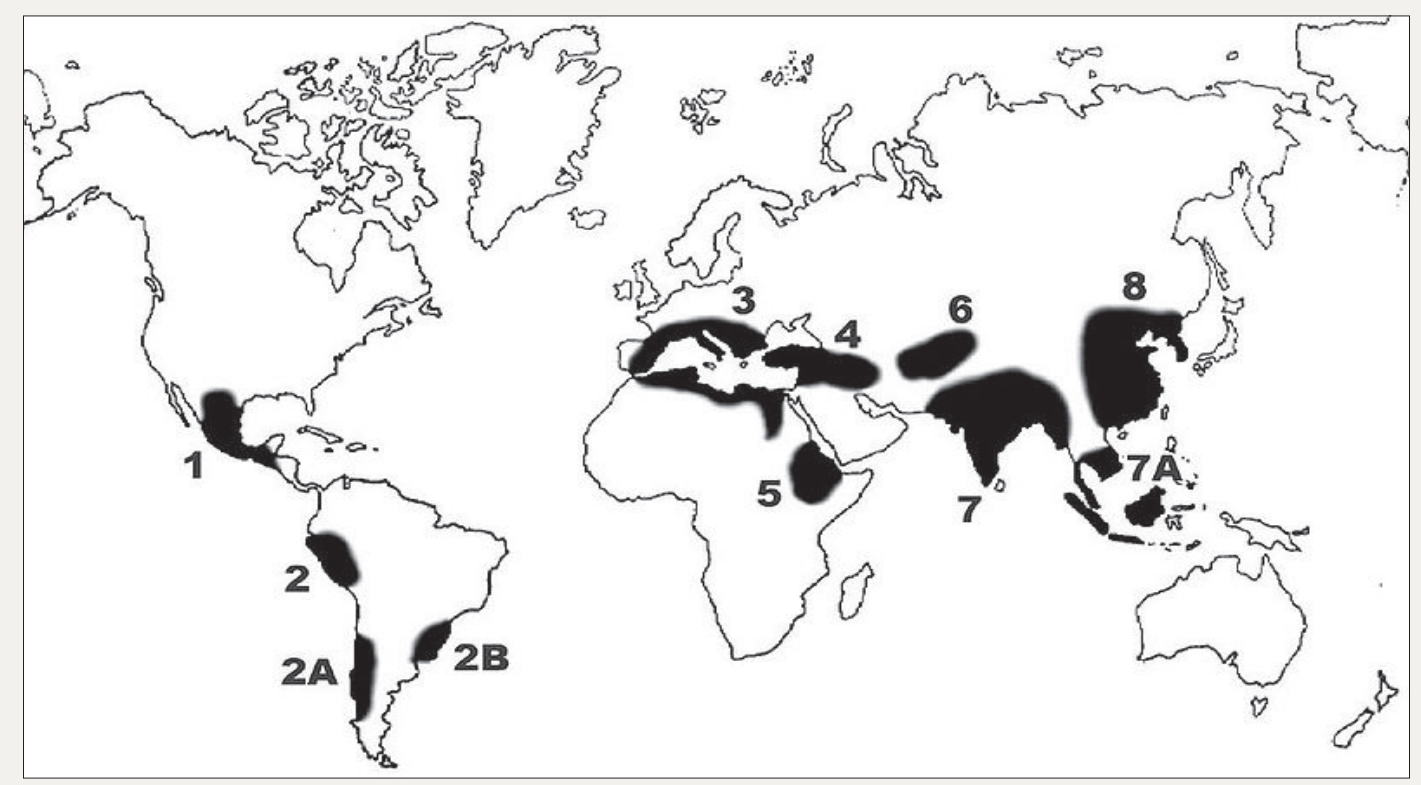

Figure 2: World map showing Vavilov center of crop origin where Ethiopia is shown by number 5 .

Note that (1) Mexico-Guatemala, (2) Peru-Ecuador-Bolivia, (2A) Southern Chile, (2B) Southern Brazil, (3) Mediterranean, (4) Middle East, (5) Ethiopia, (6) Central Asia, (7) Indo-Burma, (7A) Siam-Malaya-Java, (8) China and Korea

\section{References}

1. Sebsebe D, Friis I (2009) Natural vegetation of the Flora area. In: Hedberg I, Friis I, Persson (Eds.), Flora of Ethiopia and Eritrea, Uppsala, Sweden, 8: 27-38.

2. Dawit A, Ahadu A (1993) Medicinal plants and enigmatic health practice of North Ethiopia. Berehanina Selam Printing Enterprise, Addis Ababa Ethiopia.
3. De Candolle A (1882) Origins de plantes cultivees. Paris, France.

4. Vavilov NI (1940) The theory of the origin of cultivated plants after Darwin. Soviet Science 2: 55-75.

5. Vavilov NI (1951) The origin, variation, immunity and breeding of cultivated plants, Chronica Botanica13: 1-366.

6. Vavilov NI (1992) Origin and geography of cultivated plants. Cambridge University Press, Cambridge, UK.
Creative Commons Attribution 4.0

International License

For possible submissions Click Here

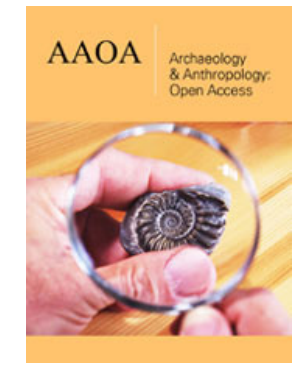

\section{Archaeology \& Anthropology: Open Access}

\section{Benefits of Publishing with us}

- High-level peer review and editorial services

- Freely accessible online immediately upon publication

- Authors retain the copyright to their work

- Licensing it under a Creative Commons license

- Visibility through different online platforms 